\title{
Ethnoveterinary Medicines: A Potential Alternative to Animal Health Care for the Tribal Communities of Koraput, Odisha
}

\author{
Kartik Charan Lenka ${ }^{1}$, Naina Pradhan², Bandana Padhan ${ }^{3, *}$ \\ ${ }^{1}$ M.S. Swaminathan Research Foundation, Jeypore \\ ${ }^{2}$ Khariar Autonomous College, Khariar, Nuapada \\ ${ }^{3}$ Department of Biodiversity and Conservation of Natural Resources, \\ Central University of Orissa, Koraput \\ *miki.bandana@gmail.com
}

Keywords: Ethnoveterinary, Koraput, Medicinal plants, Veterinary ailments, Livestock

\begin{abstract}
Medicinal plants play an important role throughout the world for the treatment and prevention of various diseases of both human and animal. The tribal communities of Koraput still depends on medicinal plants for their first aid remedies to treat some simple ailments of livestock. The present study was initiated to quantitatively document their indigenous knowledge on the utilization of most common medicinal plants for livestock treatment. A total of 40 field surveys were carried out from August 2015 to October 2016 in order to document the utilization of medicinal plants. The ethnoveterinary information was collected through structure interviews among the traditional healers and local livestock farmers. The collected data were analyzed through use value (UV), informant consensus factor (Fic) and fidelity level (FL). A total of 56 species of plants distributed in 54 genera belonging to 36 families were identified as commonly used medicinal plants by the tribal communities of Koraput for the treatment of 20 types of ailments. These ailments were categorized into 9 ailment categories based on the body systems treated. Leaves were the most frequently used plant parts and most of the medicines were prepared in the form of paste and administered orally. Fic values of the present study indicated that there was a high agreement in the use of plants in the treatment of wound infections, dysentery and eye problems among the users. Dermatological infections/diseases and gastro-intestinal disorders had highest usereports and 2 species of plants had the highest fidelity level of 100\%. The most important species according to their use value were Curcuma longa, Ficus religiosa, Aloe vera, Ziziphus mauritiana, Tridax procumbens and Vitex negundo. As a result of the present study it can be recommend the plants Aloe vera, Azadirachta indica, Calotropis procera, Curcuma longa, Datura metel, Ficus religiosa, Ziziphus mauritiana, Vitex negundo and Tridax procumbens can be investigated further for their ethnopharmacological properties for the discovery of potential new drugs for veterinary treatment.
\end{abstract}

\section{Introduction}

Traditional medicine is a part of the indigenous knowledge system of the people all over the world. According to the World Health Organization (WHO), at least $80 \%$ of the people in developing countries depend on indigenous practices for treatment of various diseases of both human being and their animals [1]. The medicinal plants are also used extensively and quite effectively for primary health care treatment of the domestic animals [31]. The indigenous knowledge of the veterinary health care system acquired by traditional herbal healers and the information passes from one generation to other. Even though the rate of medicinal plant utility is ever increasing, very little is known about its use patterns. It is very important to document, analyze and evaluate this knowledge for their commercial value, as the medicinal plants is one of the most successful criteria used by the pharmaceutical industry in finding new therapeutic agents [2]. This growing interest in traditional practices had been encouraged by the recognition of some efficient ethnoveterinary medicinal products. 
In recent years, increasing attention has been paid to ethno veterinary knowledge and local veterinary practices. There is a growing acceptance in the field of ethnoveterinary research and development in many parts of the developing countries [17, 28, 15, 32, 14]. Some studies on ethno veterinary practices has also been reported by many researchers from different regions of India [6, $13,5,21,12,31]$. But the traditional knowledge is rapidly degrading due to modernization and gradually, these practices are hardly documented and largely lost, diluted and distorted. Therefore, the traditional knowledge of animal healthcare practices requires great attention for pharmaceutical analysis to prospect new drugs in the concerned field.

Odisha is a genetic paradise of natural resources especially Koraput is one of the tribal dominated district of south Odisha, rich in different plant resources and centres of diversity for many forest species [18] and also well known for its rich human cultural diversity [19]. There is no such report on ethnoveterinary practice of medicinal plants used by the tribal communities of Koraput. In view of this, the present study was conducted to quantitatively document the ethnoveterinary medicinal plants and their utilization for primary health care treatments of animals by the tribals of Korapur district. This study provided an inventory of medicinal plants used in ethnoveterinary practices against different diseases and can act as a low cost option than the western drugs.

\section{Materials and Methods}

\section{Study area and tribal community}

Koraput is the Southernmost district of Odisha lies between $18^{\circ} 14^{\prime}$ to $19^{\prime}$ ' $14^{\prime}$ N latitude and $82^{\circ} 05^{\prime}$ to $83^{\circ} 25^{\prime}$ E longitude with a total geographical area of $8,807 \mathrm{sq} \mathrm{km}(5.38 \%$ of Odisha state) (Fig. 1) Physio-graphically it is contiguous to the main land of Eastern Ghats, High land zone and South-Eastern Ghats zone. The general topography is of broken mountains interrupted by large riverbeds and water courses. Fifty two tribal communities constituting $50.56 \%$ of its population live in the district as per the census details of 2011 [18]. The study was conducted in 60 different tribal villages of Koraput district which are inhabited by different tribal communities in the deep forest areas. A total of 40 field surveys were carried out from August 2015 to October 2016 in order to document the utilization of medicinal plants. The indigenous people of the study area are Paraja, Bhumia and Bhatra, the oldest tribal group of the branch of ethnic group in Odisha. They live predominantly in the villages mainly closer to the deepest forest. Most of the tribal have a general knowledge of medicinal plants that are used for first aid remedies, to treat the simple ailments of their animals. 


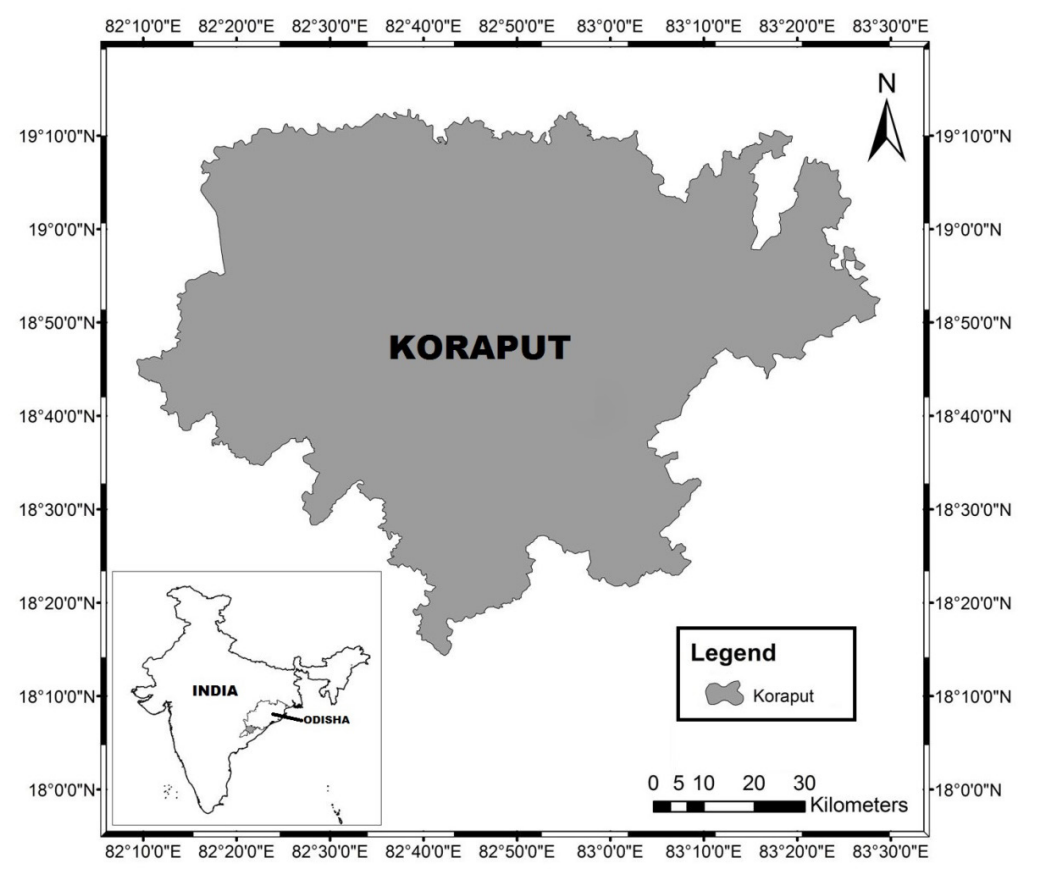

Figure 1. Map showing the origin study area from Koraput, Odisha.

\section{Data collection}

Information on ethno-veterinary medicinal plants was collected from different respondents of diversified age groups of different tribal communities of Koraput. A total of sixty four informants with traditional healers were identified to get the ethnoveterinary information by structured questionnaires through direct interviews/oral conversations. They have sound knowledge on medicinal plants found in their surrounding areas and they practice medicine within their families and neighbors. Information on local name of plant, plant part used for curing, method of preparation, any other plants/agents used as ingredients, modes of administration and etc. were recorded. The plants were collected and identified by following the flora of Orissa by Saxena and Brahmam [27] and Botany of Bihar [9].

\section{Ailment categories}

Based on the information obtained from the traditional healers in the study area, all the reported ailments were categorized into nine categories such as gastro-intestinal ailments (GIA), dermatological infections/diseases (DID), respiratory systems diseases (RSD), genito-urinary ailments (GUD), fever (FVR), skeleto-muscular system disorders (SMSD), poisonous bites (PB), eye problems (ED) and helminthes diseases (HD). Several diseases were placed in one ailment category based on the body systems treated.

\section{Informant Consensus Factor (Fic)}

The informant consensus factor (Fic) was used to determine the acceptance of the plants in the ailment categories by the users of the study area. The Fic was calculated by using the following formula [11].

$$
\text { Fic }=\text { Nur }-\mathrm{Nt} / \mathrm{Nur}-1,
$$

where Nur refers to the number of use-reports for a particular ailment category and Nt refers to the number of species used for a particular ailment category by all informants.

\section{Use Value (UV)}

The relative importance of each plant species used to treat various diseases known locally to be is reported as use value (UV) and it was calculated using the following formula [20]. 


$$
\mathrm{UV}=\Sigma \mathrm{U} / \mathrm{n},
$$

where UV is the use value of a species, $U$ is the number of use reports cited by each informant for a given plant species and $\mathrm{n}$ is the total number of informants interviewed for a given plant.

\section{Fidelity Level (FL)}

The fidelity level (FL) determine the most frequently used plant species for treating a particular ailment category by the informants. The FL was calculated using the following formula [4].

$$
\mathrm{FL}(\%)=\mathrm{Np} / \mathrm{N} \times 100,
$$

where $\mathrm{Np}$ is the number of use-reports cited for a given species for a particular ailment category and $\mathrm{N}$ is the total number of use reports cited for any given species.

\section{Result and Discussion}

\section{Documentation of indigenous ethnoveterinary knowledge}

A total of 56 species of plants distributed in 54 genera belonging to 36 families which were commonly used for the treatment of 20 different ailments by the tribal healers of Koraput. The plant species under the family of Euphorbiaceae was prominent having four species, followed by Caesalpiniaceae, Fabaceae, Lamiaceae, Liliaceae, Mimosaceae and Poaceae with three species each. The scientific name of the plant, family, local name, life form, use value, parts used, ailments treated with method of preparation and mode of application were presented in Table 1 in Appendix. The information on the medicinal values of the plants documented in our study area were compared with the earlier information reported by the researchers from other parts of India. No such plants were reported as a new medicinal plants as all the plants were reported with different uses by other researches of India [31, 6, 13].

\section{Life form and parts used for the preparation of ethnoveterinary medicine}

The present study revealed that the plants under trees categories were the primary source of medicine (38\%) followed by herb (34\%), shrubs (23\%) and creeper (5\%) (Fig. 2). Leaves (51\%) were most frequently used for the preparation of medicine or mixed with other plant parts among the other plant parts used, followed by whole plant (20\%) fruit (10\%), stem bark (10\%), stem (4\%), root $(4 \%)$, latex $(3 \%)$, root and seed(1\% each) (Fig. 3). This result is consistent with the previously reported study by the researchers of the country where they also reported the use of plant leaves for the preparation of herbal medicines by many indigenous communities $[31,5,6,13,22,10,24,26]$. The Leaves can be easily collected than the other parts of the plant and they are active in photosynthesis and production of secondary metabolites which may be the reason to use the leaves for herbal medicine preparation $[7,8]$.

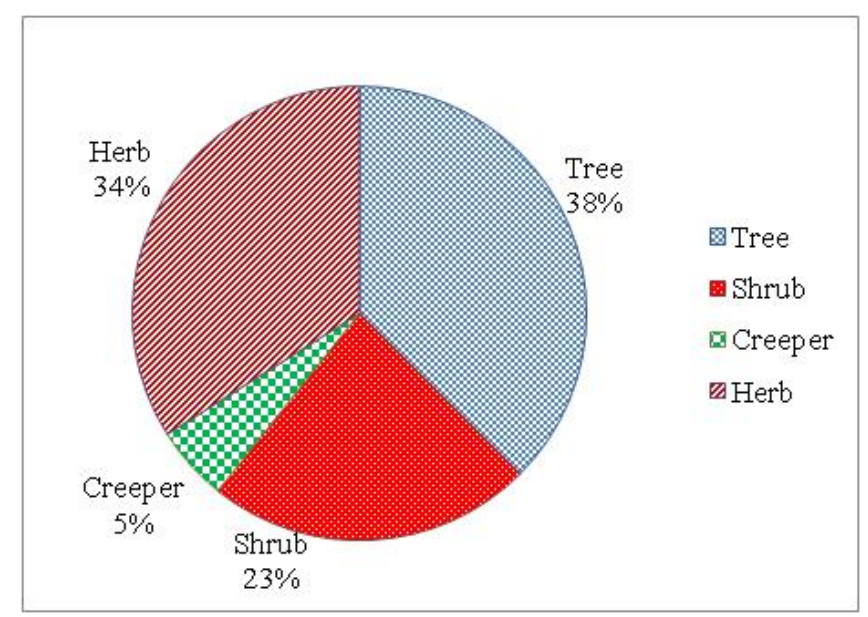

Figure 2. Life forms of reported medicinal plants. 


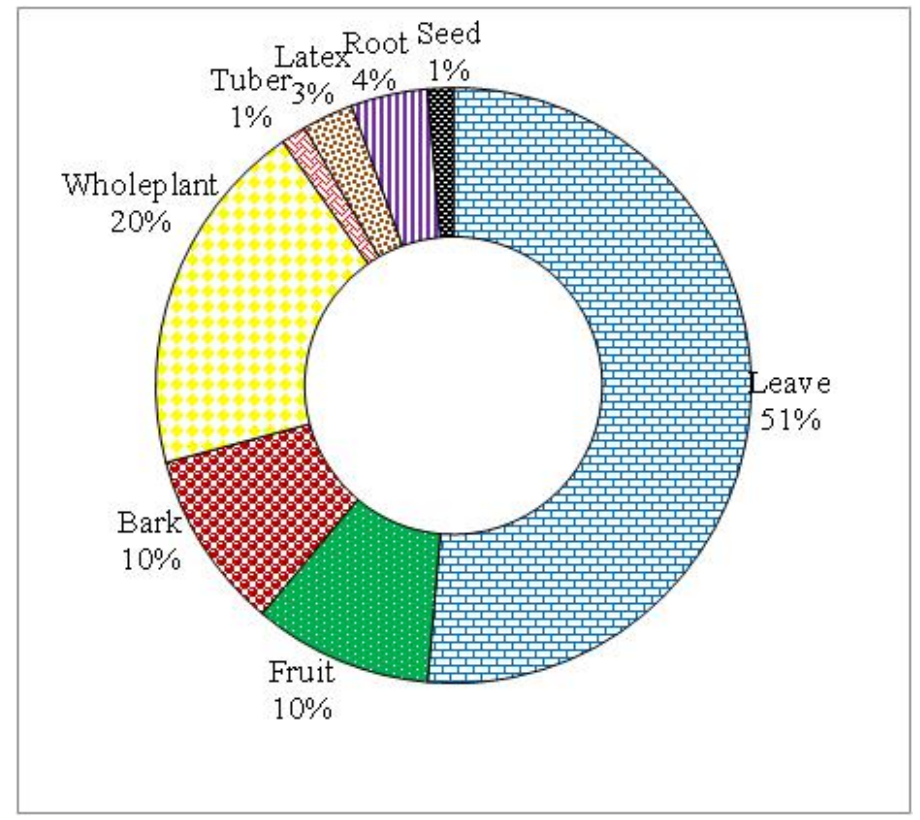

Figure 3. Percentage of plant parts used for the preparation of medicine.

\section{Mode of administration of plants and method of preparation}

The use and preparation of medicinal plant parts were grouped into four categories (Fig. 4). Most commonly used method of preparation for the herbal medicine was paste $(51 \%)$ followed by used as feed stuff $(28 \%)$, juice $(13 \%)$ and decoction (8\%). Preparation of paste for the treatment of different ailments is a common practice in human and animal healthcare system among the tribals in India $[1,16]$. The fresh leave or bark paste was prepared with oil or water and the decoction was prepared by boiling the plant parts in water until the volume was reduced to required amount. In the present study most of the tribal healers suggested that internal uses (74\%) of the herbal preparation were predominant over external or topical uses $(26 \%)$. The plant paste or medicated oil were used topical and directly applied on the affected area for the treatment of diseases like skin disorders, wounds, poison bites, dysentery and stomach worm.

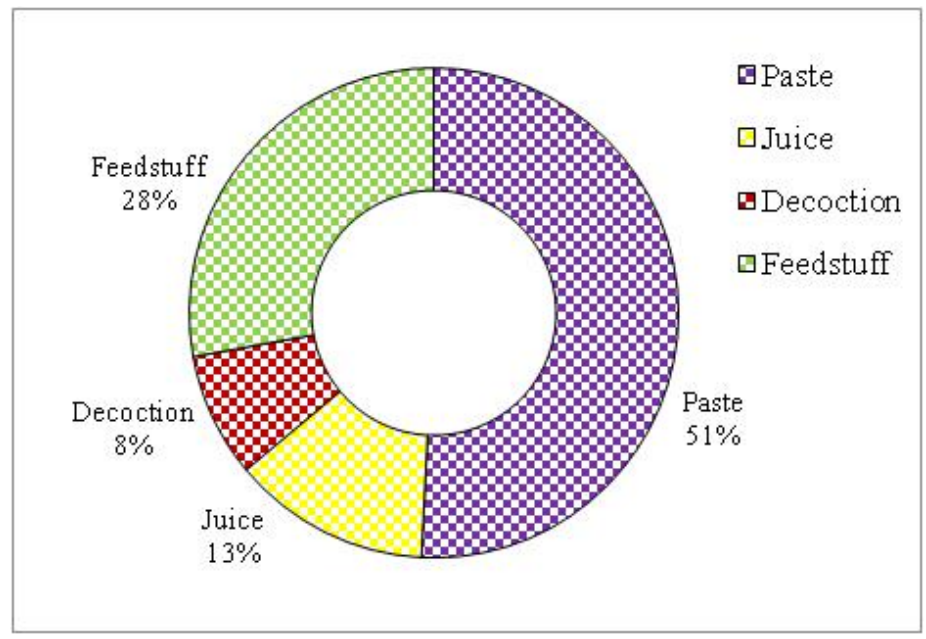

Figure 4. Categories of mode of utilization for the preparation of medicine.

\section{Plant use values}

The most commonly used species was Curcuma longa with 109 use-reports by 64 informants, giving the highest use value of 1.76. Curcuma longa is use in the treatment of various diseases in all animals and it is well known as traditional spice of India with antiseptic properties . Other important plants with high use value were Ficus religiosa (85 use reports by 64 informants with a UV of 1.33), where as Aloe vera, Ziziphus mauritiana, Tridax procumbens and Vitex negundo (76 use- 
reports by 64 informants with a UV of 1.18). The plant with very low use value was Phoenix acaulis which is reported by only seven informants with UV of 0.11 , but the informant is regularly using this plant in the treatment of stomach worms in case of calf, goat and sheep. The scarce availability of these plants in the study area may be the reason for low use value [25] as in the case of Koraput. Similar to our study, most of the reported plants in the present study are also used by the different types of tribal people in India for the treatment of various diseases in livestock [26, 22].

\section{Informant consensus factor}

In order to use the informant consensus factor (Fic), we classified the diseases into nine broad ailment categories. The Fic values in the present study are ranged from 0.96 to 1.00. The use categories with more than 400 use-reports were dermatological of infections/diseases (469 usereports, 15 species), gastro-intestinal diseases (405 use-reports, 12 species) and helminthes infection (245 use-reports, 10 species) (Table 2). In the present study, fever followed by eye disease had the highest Fic of 1.00 and 0.99 respectively. The informant consensus factor (Fic) determines the local knowledge of the people for the treatment of diseases which mainly depends on the availability of the plant species in the study area [23]. The least agreement between the informants was observed in the respiratory system disorder with a Fic of 0.95 (Table 2). Thus the present study indicates that the information on the use of medicinal plants in the livestock treatment shared by the users in the study area is high. Our findings showed that these ailment categories had high number of usereports among the tribal communities of Koraput with high Fic values.

Table 2. Informant consensus factor for commonly used medicinal plants for the treatment of livestock.

\begin{tabular}{llll}
\hline Ailment category & $\begin{array}{l}\text { Number of use- } \\
\text { reports (Nur) }\end{array}$ & $\begin{array}{l}\text { Number of } \\
\text { taxa (Nt) }\end{array}$ & $\begin{array}{l}\text { Informant consensus } \\
\text { factor (Fic) }\end{array}$ \\
\hline Gastro intestinal ailments & 405 & 12 & 0.97 \\
Poisonous bite & 98 & 2 & 0.98 \\
Dermatological infection/Disease & 469 & 15 & 0.97 \\
Eye disease & 201 & 4 & 0.99 \\
Fever & 231 & 8 & 1.00 \\
Respiratory system disorder & 137 & 5 & 0.95 \\
Skeleto muscular system disorders & 80 & 3 & 0.97 \\
Genito urinary diseases & 221 & 7 & 0.97 \\
Helminthes disease & 245 & 10 & 0.96 \\
$\quad$ TOTAL & 2087 & 67 & \\
\hline
\end{tabular}

\section{Fidelity level}

The ailment categories were analyzed in order to highlight the most important plants in each category (Table 3). Among the 56 reported plants, 2 species had highest fidelity level of 100\% which were used in treatment of single ailment category with multiple informants. For the analysis of fidelity level, the plants with less than seven use reports were not considered. The plants with highest FL of 100\% were Achyranthus aspera (ED) and Ficus religiosa (GUD). The maximum FL for the above plants indicated the $100 \%$ choice of the interviewed informants for treating specific ailments and this could be an indication of their healing potential. Tridax procumbens, Albizia lebbeck, Mimosa pudica, Ocimum tenuiflorum, Cassia fistula, Boerhavia diffusa, Cordia oblique, Euphobia hirta, Portulaca oleracea, Calotropis procera and Leucas aspera were documented to have above $50 \%$ of FL for treatment of various ailment category by the local tribal of Koraput. The fidelity level of the present study was comparable with the study of ethnoveterinary study of the tribal society of Sulaiman range by Tariq et al. [29]. 
Table 3. Diseases grouped by different ailment categories with fidelity level (FL) values for common medicinal plants used by tribal communities.

\begin{tabular}{|c|c|c|c|c|}
\hline Sl. no & Ailment categories & Medical terms & $\begin{array}{l}\text { Most preferred species with } \\
\text { specific ailment }\end{array}$ & $\begin{array}{l}\text { Fidelity level } \\
\text { (\%) }\end{array}$ \\
\hline \multirow[t]{7}{*}{1.} & \multirow{7}{*}{$\begin{array}{l}\text { Gastro intestinal } \\
\text { ailments (GIA) }\end{array}$} & Diarrhea & Abutilon indicum & 20.00 \\
\hline & & Dysentery & Aegle marmelos & 20.00 \\
\hline & & Stomach disorder & Bambusha arundinacea & 15.38 \\
\hline & & Indigestion & Cynodon doctylon & 25.00 \\
\hline & & Piles/Constipation & Dalbergia sissoo & 15.00 \\
\hline & & & Mangifera indica & 11.11 \\
\hline & & & Ricinus communis & 21.11 \\
\hline \multirow[t]{2}{*}{2.} & \multirow[t]{2}{*}{ Poisonous bite $(\mathrm{PB})$} & Snake bite & Terminalia arjuna & 38.46 \\
\hline & & Poison consumption & Tamarindus indica & 20.00 \\
\hline \multirow[t]{4}{*}{3.} & \multirow{4}{*}{$\begin{array}{l}\text { Dermatological } \\
\text { infection/Disease } \\
\text { (DID) }\end{array}$} & Tic problem & Annona reticulata & 30.80 \\
\hline & & Wound & Cuscuta reflexa & 30.80 \\
\hline & & & Tridax procumbens & 54.50 \\
\hline & & & Cassia tora & 21.40 \\
\hline \multirow[t]{2}{*}{4.} & \multirow[t]{2}{*}{ Eye disease (ED) } & Tearing of eye & Achyranthes aspera & 100.00 \\
\hline & & & Albizia lebbeck & 56.10 \\
\hline \multirow[t]{3}{*}{5.} & \multirow[t]{3}{*}{ Fever (FVR) } & Fever & Andrographis paniculata & 42.86 \\
\hline & & Pox & Mimosa pudica & 66.67 \\
\hline & & & Pongamia pinnata & 42.86 \\
\hline \multirow[t]{2}{*}{6.} & \multirow{2}{*}{$\begin{array}{l}\text { Respiratory system } \\
\text { disorder (RSD) }\end{array}$} & Cough & Ocimum tenuiflorum & 70.00 \\
\hline & & Cold & Cassia fistula & 58.78 \\
\hline \multirow[t]{2}{*}{7.} & Skeleto muscular & Fracture & Abrus precatorius & 15.00 \\
\hline & $\begin{array}{l}\text { system disorders } \\
\text { (SMSD) }\end{array}$ & Joint swelling & Azadirachta indica & 21.05 \\
\hline \multirow[t]{6}{*}{8.} & Genito urinary & Lactation & Asparagous recemosus & 21.00 \\
\hline & diseases (GUD) & Pregnency delivery & Ficus religiosa & 100.00 \\
\hline & & Fertility & Boerhavia diffusa & 81.00 \\
\hline & & & Cordia obliqua & 75.60 \\
\hline & & & Euphobia hirta & 74.00 \\
\hline & & & Portulaca oleracea & 53.43 \\
\hline \multirow[t]{4}{*}{9.} & \multirow{4}{*}{$\begin{array}{l}\text { Helminthes disease } \\
\text { (HD) }\end{array}$} & Helminthes infection & Bryophyllum pinnatum & 33.33 \\
\hline & & Worm infection & Calotropis procera & 71.43 \\
\hline & & & Carica papaya & 50.00 \\
\hline & & & Leucas aspera & 65.00 \\
\hline
\end{tabular}

\section{Reliability of reported uses}

The plants which are used in more than one ailment could have biologically active component or pharmacologically active components [30]. The tribals of Koraput used the bark decoction of Ficus religiosa for easy delivery of calf and to maintain the pregnancy with a use value of 1.33 and FL of $100 \%$. Most of the plants reported in this study have more use value and Fic which indicate the effectiveness of the plant to treat various ailments in livestock. This indicates that locally available plant populations are a major determinant of the plant species used in ethnoveterinary medicines in the study area. In support of our study, Ficus religiosa, Ziziphus mauritiana has been reported by other researches for the presence of various metabolites which implies a good ethnoveterinary medicinal plants $[17,31]$. The ethnoveterinary studies evident that, the efficiency of these reported plants species should be investigate to proven the drugs used in modern medicines [3].

\section{Conclusion}

The traditional folk medicines were still practiced by the tribal communities and only a few individuals in the tribal communities have accurate knowledge on the medicinal application of the plants. Thus, our work would be useful in preventing the loss of ethnoveterinary traditions of the tribal communities. The plants with highest fidelity level and use values in the present study may indicate the possible occurrence of valuable phytochemicals. The efficacy and safety of all the 
reported ethnoveterinary plants needs to be evaluated for phytochemical and pharmacological studies to carry out future bioassay and toxicity studies. Among all the reported plant species, Aloe vera, Azadirachta indica, Calotropis procera, Curcuma longa, Datura metel, Ficus religiosa, Ziziphus mauritiana, Vitex negundo and Tridax procumbens had the high use values which may be use further for ethnopharmacological studies. These ethnoveterinary medicinal plants can be a cheap and readily available alternative source of medicines to costly drugs. Hence a need for detailed investigation of ethnoveterinary knowledge held by each tribal community is required before such valuable knowledge vanishes.

\section{Appendix}

Table 1. List of commonly used medicinal plants used by tribals of South Odisha for the treatment of various diseases of animal. Gastro intestinal ailments (GIA); Poisonous bite (PB); Dermatological infection/Disease (DID); Eye disease (ED); Fever (FVR); Respiratory system disorder (RSD); Skeleto muscular system disorders (SMSD); Genito urinary diseases (GUD); Helminthic disease (HD).

\begin{tabular}{|c|c|c|c|c|c|c|c|c|c|c|}
\hline 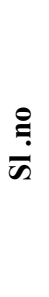 & 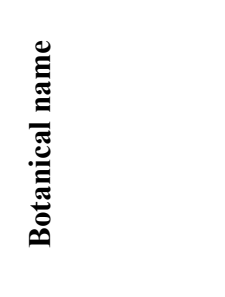 & $\frac{\mathscr{E}}{\stackrel{\Xi}{\Xi}}$ & 离 & $\stackrel{\Xi}{\Xi}$ & 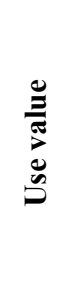 & 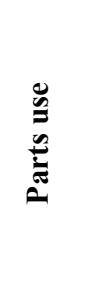 & 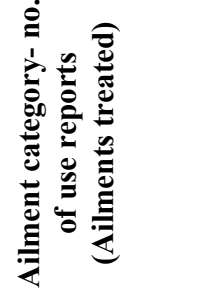 & 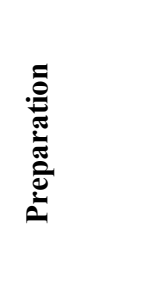 & & 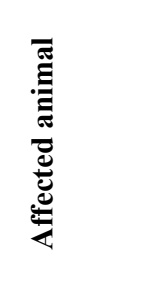 \\
\hline 1. & $\begin{array}{l}\text { Abrus } \\
\text { precatorius L. }\end{array}$ & Gunja & Fabaceae & Creeper & 0.67 & $\begin{array}{l}\text { Leaf } \\
\text { and } \\
\text { seed }\end{array}$ & $\begin{array}{l}\text { SMSD- 43 } \\
\text { (muscular } \\
\text { swelling) }\end{array}$ & Paste & Topical & $\begin{array}{l}\text { Cow and } \\
\text { Buffaloes }\end{array}$ \\
\hline 2. & $\begin{array}{l}\text { Abutilon } \\
\text { indicum (L.) }\end{array}$ & Pedipedika & Malvaceae & Shrub & 0.83 & Leaf & $\begin{array}{l}\text { GIA- } 53 \\
\text { (dysentery) }\end{array}$ & Paste & Oral & $\begin{array}{l}\text { Goat and } \\
\text { Sheep. }\end{array}$ \\
\hline 3. & $\begin{array}{l}\text { Acacia } \\
\text { nilotica (L.) } \\
\text { Delile. }\end{array}$ & Bamura & Mimosaceae & Tree & $\begin{array}{l}0.50 \\
0.21\end{array}$ & Leaf & $\begin{array}{l}\text { GIA- } 32 \\
\text { (diarrhoea) } \\
\text { HD- } 13 \\
\text { ( stomach } \\
\text { worms) }\end{array}$ & Paste & Oral & $\begin{array}{l}\text { Cow and } \\
\text { Buffaloes }\end{array}$ \\
\hline 4. & $\begin{array}{l}\text { Acalypha } \\
\text { indica } \mathrm{L} \text {. }\end{array}$ & Indramaricha & Euphorbiaceae & Herb & $\begin{array}{l}0.37 \\
0.21\end{array}$ & Leaf & $\begin{array}{l}\text { DID- } 24 \\
\text { (wounds) } \\
\text { RSD- } 13 \text { (cold } \\
\text { and cough) }\end{array}$ & Paste & $\begin{array}{l}\text { Topical } \\
\text { Oral }\end{array}$ & $\begin{array}{l}\text { Goat and } \\
\text { Sheep }\end{array}$ \\
\hline 5. & $\begin{array}{l}\text { Achyranthes } \\
\text { aspera } \mathrm{L} .\end{array}$ & Apamaranga & Amaranthaceae & Herb & 0.87 & Leaf & $\begin{array}{l}\text { ED-56 } \\
\text { (watering in } \\
\text { eyes) }\end{array}$ & Juice & Internal & $\begin{array}{l}\text { Cow and } \\
\text { Buffaloes }\end{array}$ \\
\hline 6. & $\begin{array}{l}\text { Adhatoda } \\
\text { vasica Nees. }\end{array}$ & Basanga & Acanthaceae & Shrub & 0.32 & Leaf & $\begin{array}{l}\text { FVR- } 21 \\
\text { (fever) }\end{array}$ & Decoction & Oral & $\begin{array}{l}\text { Goat and } \\
\text { Sheep. }\end{array}$ \\
\hline 7. & $\begin{array}{l}\text { Aegle marmelos } \\
\text { (L.) Correa. }\end{array}$ & Bela & Rutaceae & Tree & 0.76 & Fruit & $\begin{array}{l}\text { DID- } 49 \\
\text { (dysentery } \\
\text { and diarrhoea) }\end{array}$ & Paste & Oral & $\begin{array}{l}\text { Goat and } \\
\text { Sheep }\end{array}$ \\
\hline 8. & $\begin{array}{l}\text { Albizia lebbeck } \\
\text { (L.) Benth. }\end{array}$ & Sirisa & Mimosaceae & Tree & 0.76 & Leafs & $\begin{array}{l}\text { ED-49 (eye } \\
\text { problem). }\end{array}$ & Juice & Internal & $\begin{array}{l}\text { Goat, } \\
\text { Cow and } \\
\text { Buffalo }\end{array}$ \\
\hline 9. & Allium cepa & Piyaja & Lilliaceae & Shrub & $\begin{array}{l}0.16 \\
0.31\end{array}$ & Leaf & $\begin{array}{l}\text { RSD- 10 (cold, } \\
\text { cough) } \\
\text { HD- } 20 \\
\text { (worm) }\end{array}$ & Juice & Oral & $\begin{array}{l}\text { Goat and } \\
\text { Cow }\end{array}$ \\
\hline 10. & $\begin{array}{l}\text { Aloe } \\
\text { vera (L.) Burm } \\
\text { f. }\end{array}$ & Ghiakuanri & Lilliaceae & Herb & 1.18 & $\begin{array}{l}\text { Whole } \\
\text { plant }\end{array}$ & $\begin{array}{l}\text { ED- } 76 \\
\text { (tearing of } \\
\text { eye) }\end{array}$ & Juice & Internal & $\begin{array}{l}\text { Cow and } \\
\text { Buffalo }\end{array}$ \\
\hline
\end{tabular}




\begin{tabular}{|c|c|c|c|c|c|c|c|c|c|c|}
\hline & $\begin{array}{l}\text { Andrographis } \\
\text { paniculata } \\
\text { Nees. }\end{array}$ & Bhuinnimba & Acanthaceae & Herb & $\begin{array}{l}0.11 \\
0.23\end{array}$ & $\begin{array}{l}\text { Whole } \\
\text { plant }\end{array}$ & $\begin{array}{l}\begin{array}{l}\text { FVR- } 7 \\
\text { (fever) }\end{array} \\
\text { RSD- } 15 \\
\text { (cough) }\end{array}$ & Decoction & Oral & Goat \\
\hline 12. & $\begin{array}{l}\text { Annona } \\
\text { reticulata Linn. }\end{array}$ & Sitaphala & Annonaceae & Tree & 0.24 & Leaf & $\begin{array}{l}\text { DID- } 15 \text { ( tics } \\
\text { and lice) }\end{array}$ & Paste & Topical & $\begin{array}{l}\text { Cow and } \\
\text { Buffalo }\end{array}$ \\
\hline 13. & $\begin{array}{l}\text { Argemone } \\
\text { mexicana } \mathrm{L} .\end{array}$ & Bhejiri kanta & Papaveraceae & Herb & 0.42 & $\begin{array}{l}\text { Whole } \\
\text { plant }\end{array}$ & $\begin{array}{l}\text { GIA-27 } \\
\text { (constipation) }\end{array}$ & $\begin{array}{l}\text { Whole } \\
\text { plant }\end{array}$ & Oral & $\begin{array}{l}\text { Cow and } \\
\text { Buffalo }\end{array}$ \\
\hline 14. & $\begin{array}{l}\text { Asparagus } \\
\text { recemosus } \\
\text { Willd. }\end{array}$ & Satavari & Liliaceae & Creeper & 1.05 & Tuber & $\begin{array}{l}\text { GUD-67 (heat } \\
\text { production) }\end{array}$ & $\begin{array}{l}\text { Whole } \\
\text { tuber }\end{array}$ & Oral & $\begin{array}{l}\text { Cow and } \\
\text { Buffalo }\end{array}$ \\
\hline 15. & $\begin{array}{l}\text { Azadirachta } \\
\text { indica A. Juss. }\end{array}$ & Nimba & Meliaceae & Tree & $\begin{array}{l}0.42 \\
0.23 \\
0.11\end{array}$ & Leaf & $\begin{array}{l}\text { GIA-27 } \\
\text { (stomachache) } \\
\text { SMSD-15 } \\
\text { (fractured } \\
\text { horns) } \\
\text { DID-7 } \\
\text { (injury) }\end{array}$ & Paste & $\begin{array}{l}\text { Oral and } \\
\text { Topical }\end{array}$ & $\begin{array}{l}\text { Cow and } \\
\text { Buffalo } \\
\text { Bird and } \\
\text { parrots } \\
\text { (heal } \\
\text { injury) }\end{array}$ \\
\hline 16. & $\begin{array}{l}\text { Bambusha } \\
\text { arundinacea (L) } \\
\text { Schreb }\end{array}$ & Baunsa & Poaceae & Shrub & 1.08 & Leaf & $\begin{array}{l}\text { GID-69 } \\
\text { (dysentery) }\end{array}$ & Juice & Oral & Cow \\
\hline 17. & $\begin{array}{l}\text { Boerhaavia } \\
\text { diffusa } \mathrm{L} \text {. }\end{array}$ & Puruni & Nyctaginaceae & Herb & 0.18 & $\begin{array}{l}\text { Whole } \\
\text { plant }\end{array}$ & $\begin{array}{l}\text { GUD- } 12 \\
\text { (easy delivery } \\
\text { of calf) }\end{array}$ & Feed stuff & Oral & $\begin{array}{l}\text { Cow and } \\
\text { Buffaloes }\end{array}$ \\
\hline 18. & $\begin{array}{l}\text { Bryophyllum } \\
\text { pinnatum } \\
\text { (Lam.) Kurz }\end{array}$ & Patragaja & Crassulaceae & Shrub & 0.18 & Leafs & $\begin{array}{l}\text { HD -12 } \\
\text { (stomach } \\
\text { worm) }\end{array}$ & Feed stuff & Oral & Cow \\
\hline 19. & $\begin{array}{l}\text { Calotropis } \\
\text { procera (Aiton) } \\
\text { Dryand. }\end{array}$ & Arakha & Asclepiadaceae & Shrub & $\begin{array}{l}0.16 \\
0.23 \\
0.37\end{array}$ & $\begin{array}{l}\text { Leafs } \\
\text { and } \\
\text { root }\end{array}$ & $\begin{array}{l}\text { HD-10 } \\
\text { (worms) } \\
\text { GUD- } 15 \\
\text { (increase the } \\
\text { milk quantity) } \\
\text { DID- } 24 \\
\text { (wound) }\end{array}$ & $\begin{array}{l}\text { Feed stuff, } \\
\text { Root paste }\end{array}$ & $\begin{array}{l}\text { Oral and } \\
\text { Topical } \\
\text { (wound) }\end{array}$ & $\begin{array}{l}\text { Sheep, } \\
\text { Goat, } \\
\text { Cow and } \\
\text { Buffaloes }\end{array}$ \\
\hline 20. & $\begin{array}{l}\text { Cardiospermum } \\
\text { halicacabum }\end{array}$ & Phutuphutika & Sapindaceae & Shrub & 1.00 & $\begin{array}{l}\text { Whole } \\
\text { plant }\end{array}$ & $\begin{array}{l}\text { FVR- } 64 \\
\text { (fever) }\end{array}$ & Paste & Oral & $\begin{array}{l}\text { Goat, and } \\
\text { Cow }\end{array}$ \\
\hline 21. & $\begin{array}{l}\text { Carica } \\
\text { papaya Linn. }\end{array}$ & Amruta bhanda & Cari caceae & Tree & 1.00 & Fruit & $\begin{array}{l}\text { HD- } 64 \\
\text { (Worms) }\end{array}$ & Juice & Oral & $\begin{array}{l}\text { Sheep, } \\
\text { Goat, } \\
\text { Cow, } \\
\text { Buffaloes } \\
\text { and Birds }\end{array}$ \\
\hline 22. & $\begin{array}{l}\text { Cassia } \\
\text { fistula } \mathrm{L} .\end{array}$ & Sunari & Caesalpiniaceae & Tree & 0.79 & Bark & $\begin{array}{l}\text { RSD - 51 } \\
\text { (cough) }\end{array}$ & Paste & Oral & $\begin{array}{l}\text { Sheep, } \\
\text { Goat, } \\
\text { Cow and } \\
\text { Buffaloes }\end{array}$ \\
\hline 23. & $\begin{array}{l}\text { Cassia } \\
\text { tora } \mathrm{L} .\end{array}$ & Chakunda & Caesalpiniaceae & Tree & 0.50 & $\begin{array}{l}\text { Leaf } \\
\text { and } \\
\text { seed }\end{array}$ & $\begin{array}{l}\text { DID- } 32 \text { (skin } \\
\text { diseases and } \\
\text { wound ) }\end{array}$ & Paste & Topical & $\begin{array}{l}\text { Sheep } \\
\text { and Goat }\end{array}$ \\
\hline 24. & $\begin{array}{l}\text { Cassius } \\
\text { quadrangularis } \\
\text { L. }\end{array}$ & Hadabhanga & Vitaceae & Herb & 0.74 & $\begin{array}{l}\text { Whole } \\
\text { plant }\end{array}$ & $\begin{array}{l}\text { DID- } 47 \\
\text { (wound) }\end{array}$ & Paste & Topical & $\begin{array}{l}\text { Sheep } \\
\text { and Goat }\end{array}$ \\
\hline 25. & $\begin{array}{l}\text { Cordia } \\
\text { obliqua Willd. }\end{array}$ & Guhgali & Boraginaceae & Tree & 0.18 & Leafs & $\begin{array}{l}\text { GUD-12 } \\
\text { (lactation) }\end{array}$ & Feed stuff & Oral & $\begin{array}{l}\text { Sheep, } \\
\text { Goat, } \\
\text { Cow and } \\
\text { Buffaloes }\end{array}$ \\
\hline 26. & $\begin{array}{l}\text { Curcuma } \\
\text { longa Linn. }\end{array}$ & Haldi & Zingiberaceae & Herb & $\begin{array}{l}1.24 \\
0.21 \\
0.31\end{array}$ & Root & $\begin{array}{l}\text { GID- } 76 \\
\text { ( loose } \\
\text { motion) } \\
\text { HD-13 } \\
\text { (stomach } \\
\text { worms ) } \\
\text { DID- 20 } \\
\text { (wound ) }\end{array}$ & Paste & Oral & $\begin{array}{l}\text { Sheep, } \\
\text { Goat, } \\
\text { Cow and } \\
\text { Buffaloes }\end{array}$ \\
\hline 27. & $\begin{array}{l}\text { Cuscuta } \\
\text { reflexa Roxb. } \\
\text {. }\end{array}$ & Nirmuli & Convolvulaceae & Creeper & 1.13 & $\begin{array}{l}\text { Whole } \\
\text { plant }\end{array}$ & $\begin{array}{l}\text { DID- } 72 \\
\text { (remove } \\
\text { worms in } \\
\text { wound) }\end{array}$ & Paste & Topical & $\begin{array}{l}\text { Cow and } \\
\text { Buffaloes }\end{array}$ \\
\hline
\end{tabular}




\begin{tabular}{|c|c|c|c|c|c|c|c|c|c|c|}
\hline 28. & $\begin{array}{l}\text { Cymbopogen } \\
\text { citratus }\end{array}$ & Dhanwantari & Poaceae & Shrub & 0.55 & $\begin{array}{l}\text { Whole } \\
\text { plant }\end{array}$ & $\begin{array}{l}\text { DID- } 35 \text { (anti } \\
\text { tics and lice) }\end{array}$ & Paste & Topical & $\begin{array}{l}\text { Cow and } \\
\text { Buffaloes }\end{array}$ \\
\hline 29. & $\begin{array}{l}\text { Cynodon } \\
\text { dactylon }(\mathrm{L}) \\
\text { christias } \\
\text { hendrik pers }\end{array}$ & Duba ghasa & Poaceae & Herb & 1.00 & $\begin{array}{l}\text { Whole } \\
\text { plant }\end{array}$ & $\begin{array}{l}\text { GID-64 } \\
\text { (stomach } \\
\text { problems) }\end{array}$ & Feed stuff & Oral & $\begin{array}{l}\text { Sheep, } \\
\text { Goat, } \\
\text { Cow and } \\
\text { Buffaloes }\end{array}$ \\
\hline 30. & $\begin{array}{l}\text { Dalbergia } \\
\text { sissoo Roxb. }\end{array}$ & Sisu & Febaceae & Tree & 0.26 & Leaf & $\begin{array}{l}\text { GID-17 (loose } \\
\text { motion) }\end{array}$ & Feed stuff & Oral & $\begin{array}{l}\text { Sheep, } \\
\text { Goat, } \\
\text { Cow and } \\
\text { Buffaloes }\end{array}$ \\
\hline 31. & $\begin{array}{l}\text { Datura } \\
\text { metel L. }\end{array}$ & Dudura & Solanaceae & Shrub & $\begin{array}{l}0.53 \\
0.21 \\
0.34\end{array}$ & $\begin{array}{l}\text { Fruit, } \\
\text { Leaf }\end{array}$ & $\begin{array}{l}\text { GID- } 34 \\
\text { (dysentery) } \\
\text { RSD- 13 } \\
\text { (cough) } \\
\text { SMSD- 22 } \\
\text { (pain and } \\
\text { swelling) }\end{array}$ & $\begin{array}{l}\text { Feedstuff, } \\
\text { leaf paste }\end{array}$ & $\begin{array}{l}\text { Oral } \\
\text { Topical }\end{array}$ & $\begin{array}{l}\text { Sheep, } \\
\text { Goat, } \\
\text { Cow and } \\
\text { Buffaloes }\end{array}$ \\
\hline 32. & $\begin{array}{l}\text { Eclipta } \\
\text { alba (L.) } \\
\text { Hassk. }\end{array}$ & Kalabhaunra & Asteraceae & Herb & 0.24 & Leaf & $\begin{array}{l}\text { DID- } 21 \\
\text { ( wound ) }\end{array}$ & Paste & Topical & Cow \\
\hline 33. & $\begin{array}{l}\text { Euphobia } \\
\text { hirta L. }\end{array}$ & Gadni & Euphorbiacea & Shrub & 0.34 & $\begin{array}{l}\text { Latex , } \\
\text { whole } \\
\text { plant }\end{array}$ & $\begin{array}{l}\text { DID- } \\
3 \text { (wound) } \\
\text { Whole plant is } \\
\text { used as } \\
\text { feedstuff for } \\
\text { increase milk } \\
\text { production }\end{array}$ & $\begin{array}{l}\text { Latex } \\
\text { Feed stuff }\end{array}$ & Topical & $\begin{array}{l}\text { Sheep, } \\
\text { Goat, } \\
\text { Cow and } \\
\text { Buffaloes }\end{array}$ \\
\hline 34. & $\begin{array}{l}\text { Ficus } \\
\text { bengbalesis } \\
\text { Linn. }\end{array}$ & Bara & Moraceae & Tree & 0.32 & $\begin{array}{l}\text { Milk } \\
\text { bark }\end{array}$ & $\begin{array}{l}\text { DID- } 20 \\
\text { (wounds) }\end{array}$ & Latex & Topical & $\begin{array}{l}\text { Cow, } \\
\text { Goat, } \\
\text { Sheep and } \\
\text { Buffaloes }\end{array}$ \\
\hline 35. & $\begin{array}{l}\text { Ficus } \\
\text { religiosa } \mathrm{L} .\end{array}$ & Peepal & Moraceae & Tree & 1.33 & Bark & $\begin{array}{l}\text { GUD- } 85 \text { (ease } \\
\text { delivery) }\end{array}$ & Decoction & Oral & $\begin{array}{l}\text { Cow and } \\
\text { Buffaloes }\end{array}$ \\
\hline 36. & $\begin{array}{l}\text { Lawsonia } \\
\text { inermis L. }\end{array}$ & Manjuati & Lythraceae & Tree & 0.26 & Leafs & $\begin{array}{l}\text { GUD- } 17 \\
\text { (maintain } \\
\text { pregnancy) }\end{array}$ & Paste & Oral & $\begin{array}{l}\text { Goat and } \\
\text { Sheep }\end{array}$ \\
\hline 37. & $\begin{array}{l}\text { Leucas } \\
\text { aspera (Willd.) }\end{array}$ & Gayasha & Lamiaceae & Herb & $\begin{array}{l}0.37 \\
0.21\end{array}$ & $\begin{array}{l}\text { Whole } \\
\text { plant }\end{array}$ & $\begin{array}{l}\text { DID- } 24 \\
\text { (wound) } \\
\text { HD- } 13 \\
\text { (intestinal } \\
\text { worms) }\end{array}$ & Juice & Oral & $\begin{array}{l}\text { Goat and } \\
\text { Sheep }\end{array}$ \\
\hline 38. & $\begin{array}{l}\text { Mangifera } \\
\text { indica Linn. }\end{array}$ & Aamba & Anacardiaceae & Tree & 0.16 & Bark & $\begin{array}{l}\text { GIA- } 10 \text { (loose } \\
\text { motion) }\end{array}$ & Paste & Oral & Goat \\
\hline 39. & $\begin{array}{l}\text { Mimosa } \\
\text { pudica L. }\end{array}$ & Lajakuli & Mimosaceae & Herb & 0.16 & Leaf & $\begin{array}{l}\text { FVR -10 } \\
\text { (fever) }\end{array}$ & Paste & Oral & Cow \\
\hline 40. & $\begin{array}{l}\text { Ocimum } \\
\text { sanctum Linn. }\end{array}$ & Tulasi & Lamiaceae & Herb & 1.11 & Leaf & $\begin{array}{l}\text { FVR- 71 } \\
\text { ( smallpox) }\end{array}$ & Paste & Oral & Poultry \\
\hline 41. & $\begin{array}{l}\text { Ocimum } \\
\text { basilicum L. }\end{array}$ & Dhala dahana & Lamiaceae & Herb & 0.55 & Leaf & $\begin{array}{l}\text { RSD- } 35 \\
\text { (cold) }\end{array}$ & Juice & Oral & $\begin{array}{l}\text { Goat and } \\
\text { Sheep }\end{array}$ \\
\hline 42. & $\begin{array}{l}\text { Phoenix } \\
\text { acaulis Roxb. }\end{array}$ & Sindhi khajuri & Palmaceae & Tree & 0.11 & Leaf & $\begin{array}{l}\text { HD- } 7 \\
\text { (stomach } \\
\text { worm) }\end{array}$ & Decoction & Oral & $\begin{array}{l}\text { Calf, } \\
\text { Goat and } \\
\text { Sheep }\end{array}$ \\
\hline 43. & $\begin{array}{l}\text { Piper } \\
\text { nigram Linn. }\end{array}$ & golamaricha & Piperaceae & Herb & 0.29 & $\begin{array}{l}\text { Leaf } \\
\text { and } \\
\text { seed }\end{array}$ & $\begin{array}{l}\text { FVR- } 19 \\
\text { (chickenpox) }\end{array}$ & Paste & Oral & $\begin{array}{l}\text { Poultry } \\
\text { and birds }\end{array}$ \\
\hline 44. & $\begin{array}{l}\text { Plumbago } \\
\text { zeylanica } \mathrm{L} .\end{array}$ & $\begin{array}{l}\text { Sweta } \\
\text { chitaparu }\end{array}$ & Plumbaginaceae & Shrub & 0.16 & Leaf & $\begin{array}{l}\text { GIA- } 10 \\
\text { (improve } \\
\text { hunger and } \\
\text { digestion) }\end{array}$ & Feed stuff & Oral & Goat \\
\hline 45. & $\begin{array}{l}\text { Pongamia } \\
\text { pinnata (L.) }\end{array}$ & Karanja & Fabaceae & Tree & $\begin{array}{l}0.37 \\
0.41\end{array}$ & $\begin{array}{l}\text { Leaf } \\
\text { and } \\
\text { bark }\end{array}$ & $\begin{array}{l}\text { FVR- } 24 \\
\text { (fever) } \\
\text { GIA- } 26 \\
\text { (dysentery) }\end{array}$ & $\begin{array}{l}\text { Paste and } \\
\text { juice }\end{array}$ & Oral & $\begin{array}{l}\text { Cow, } \\
\text { Goat and } \\
\text { Sheep }\end{array}$ \\
\hline 46. & $\begin{array}{l}\text { Portulaca } \\
\text { oleracea L. }\end{array}$ & Nuni saga & Portulaceae & Herb & 0.21 & $\begin{array}{l}\text { Whole } \\
\text { plant }\end{array}$ & $\begin{array}{l}\text { GUD- } 13 \\
\text { (easy } \\
\text { delivery) }\end{array}$ & $\begin{array}{l}\text { Whole } \\
\text { plant }\end{array}$ & Oral & $\begin{array}{l}\text { Goat and } \\
\text { Cow }\end{array}$ \\
\hline 47. & $\begin{array}{l}\text { Punica } \\
\text { granatum }\end{array}$ & Dalimba & Punicaceae & Herb & 0.26 & Fruit & $\begin{array}{l}\text { HD- } 17 \\
\text { (stomach } \\
\text { worm) }\end{array}$ & $\begin{array}{l}\text { Fruit as } \\
\text { feed }\end{array}$ & Oral & $\begin{array}{l}\text { Goat and } \\
\text { Cow }\end{array}$ \\
\hline
\end{tabular}




\begin{tabular}{|c|c|c|c|c|c|c|c|c|c|c|}
\hline 48. & $\begin{array}{l}\text { Ricinus } \\
\text { communis L. }\end{array}$ & Jada & Euphorbiaceae & Shrub & $\begin{array}{l}0.37 \\
0.23\end{array}$ & $\begin{array}{l}\text { Leaf, } \\
\text { Seed oil }\end{array}$ & $\begin{array}{l}\text { GIA- } 24 \\
\text { (dysentery) } \\
\text { GIA-15 } \\
\text { (constipation) }\end{array}$ & $\begin{array}{l}\text { Whole leaf } \\
\text { as feed }\end{array}$ & Oral & $\begin{array}{l}\text { Goat and } \\
\text { Sheep }\end{array}$ \\
\hline 49. & $\begin{array}{l}\text { Rouwolfia } \\
\text { serpentina (L.) } \\
\text { G Bentham ex } \\
\text { W.S. Kurtz }\end{array}$ & Serpagandha & Euphorbiaceae & Shrub & 0.87 & Root & $\begin{array}{l}\text { GIA- } 56 \\
\text { (dysentery) }\end{array}$ & Paste & Oral & Cow \\
\hline 50. & $\begin{array}{l}\text { Solanum } \\
\text { indicum }\end{array}$ & Bhejibaigana & Solanaceae & Herb & 0.32 & Fruit & $\begin{array}{l}\text { ED- } 20 \\
\text { (watering in } \\
\text { eye) }\end{array}$ & Juice & Internal & $\begin{array}{l}\text { Cow and } \\
\text { Goat }\end{array}$ \\
\hline 51. & $\begin{array}{l}\text { Tamarindus } \\
\text { indica Linn. }\end{array}$ & Tentuli & Caesaipiniaceae & Tree & 0.76 & Fruit & $\begin{array}{l}\text { PB- } 49 \\
\text { (Poisonous } \\
\text { feed) }\end{array}$ & Fruit pulp & Oral & $\begin{array}{l}\text { Cow and } \\
\text { Oxen }\end{array}$ \\
\hline 52. & $\begin{array}{l}\text { Terminalia } \\
\text { arjuna Roxb. }\end{array}$ & Shaja & Combre taceae & Tree & 0.76 & Bark & $\begin{array}{l}\text { PB- } 49 \text { (anti } \\
\text { venom for } \\
\text { snake bite) }\end{array}$ & Paste & Topical & $\begin{array}{l}\text { Goat and } \\
\text { Sheep }\end{array}$ \\
\hline 53. & $\begin{array}{l}\text { Terminalia } \\
\text { chebula } \text { Retz. }\end{array}$ & Harida & Combretaceae & Tree & $\begin{array}{l}0.16 \\
0.23\end{array}$ & $\begin{array}{l}\text { Fruit } \\
\text { and } \\
\text { bark }\end{array}$ & $\begin{array}{l}\text { GIA- } 10 \\
\text { (digestion and } \\
\text { stomach ache) } \\
\text { FVR- } 15 \\
\text { (fever) }\end{array}$ & Decoction & Oral & $\begin{array}{l}\text { Sheep } \\
\text { and Goat }\end{array}$ \\
\hline 54. & $\begin{array}{l}\text { Tridax } \\
\text { procumbens L. }\end{array}$ & Bisalyakarani & Asteraceae & Herb & 1.18 & $\begin{array}{l}\text { Whole } \\
\text { plant }\end{array}$ & $\begin{array}{l}\text { DID-76 } \\
\text { (wound ) }\end{array}$ & Paste & Topical & $\begin{array}{l}\text { Cow and } \\
\text { Goat }\end{array}$ \\
\hline 55. & $\begin{array}{l}\text { Vitex negundo } \\
\text { L. } \\
\text { Nocchimaram }\end{array}$ & Nirgundi & Verbenaceae & Tree & 1.17 & Leaf & $\begin{array}{l}\text { GIA- } 75 \\
\text { (stomach } \\
\text { infection) }\end{array}$ & Paste & Oral & Cow \\
\hline 56. & $\begin{array}{l}\text { Ziziphus } \\
\text { mauritiana } \\
\text { Lam. }\end{array}$ & Barakoli & Rhamnaceae & Tree & $\begin{array}{l}1.18 \\
0.62\end{array}$ & $\begin{array}{l}\text { Whole } \\
\text { plant }\end{array}$ & $\begin{array}{l}\text { HD- } 76 \\
\text { (intestinal } \\
\text { worms) } \\
\text { GIA- } 40 \\
\text { (diarrhoea) }\end{array}$ & Leaf & Oral & $\begin{array}{l}\text { Goat and } \\
\text { Sheep }\end{array}$ \\
\hline
\end{tabular}

\section{References}

[1] M. Ayyanar, S. Ignacimuthu, Ethnobotanical survey of medicinal plants commonly used by Kani tribals in Tirunelveli hills of Western Ghats, India, J. Ethnopharmacol. 134 (2011) 851864.

[2] P.A. Cox, M.J. Balick, The ethnobotanical approach to drug discovery, Scientific Am. (1994) 60-65.

[3] D.S. Fabricant, N.R. Farnsworth, The value of plants used in traditional medicine for drug discovery, Environ. Health Perspect. 109 (2001) 69-75.

[4] J. Friedmen et al., A preliminary classification of the healing potential of medicinal plants, based on a rational analysis of an ethnopharmacological field survey among Bedouins in the Negev desert, Israel, J. Ethnopharmacol. 16 (1986) 275-287.

[5] S .Ganesan, M. Chandhirasekaran, A. Selvaraju, Ethno-veterinary health care practices in Southern districts of Tamil Nadu, Indian J. Trad. Knowled. 7 (2008) 347-354.

[6] S. Geetha, G. Lakshmi, P. Ranjithakani, Ethnoveterinary medicinal plants of Kollihills, Tamil Nadu, J. Econ. Taxon. Bot. 12 (2006) 284-291.

[7] A. Ghorbani, Studies on pharmaceutical ethnobotany in the region of Turkmen Sahra, north of Iran (Part 1): general results, J. Ethnopharmacol. 102 (2005) 58-68.

[8] M. Giday, Z. Asfaw, Z. Woldu, Medicinal plants of the Meinit ethnic group of Ethiopia: an ethnobotanical study, J. Ethnopharmacol. 124 (2009) 513-521.

[9] H.H. Haines, 1921-1925. The botany of Bihar and Odisha, Vol. I-III. Calcutta, Sri Gauranga Press. 
[10] V.H. Harsha, V. Shripathi, G.R. Hegde, Ethnoveterinary practices in Uttara Kannada districts of Karnataka, Indian J. Trad. Knowled. 4 (2005) 253-258.

[11] M. Heinrich et al., Medicinal plants in Mexico: healers' consensus and cultural importance, Soc. Sci. Med. 47 (1998) 91-112.

[12] M.A. Khan, M.A. Khan, M. Hussain, Ethno Veterinary medicinal uses of plants of Poonch Valley Azad Kashmir, Pak. J. Weed Sci. Res. 18(4) (2012) 495-507.

[13] S. Kiruba, S. Jeeva, S.S.M. Dhas, Enumeration of ethnoveterinary plants of Cope Comorin, Tamil Nadu, Indian J. Trad. Knowled. 7 (2006) 576-578.

[14] W.M. Kone, K.K. Atindehou, Ethnobotanical inventory of medicinal plants used in traditional veterinary medicine in Northern Cote d'Ivoire (West Africa), South Afr. J. Bot. 74 (2008) 7684.

[15] P.J. Masika, A.J. Afolayan, An ethnobotanical study of plants used for the treatment of livestock diseases in the Eastern Cape Province, South Africa. Pharm. Biol. 41 (2003) 16-21.

[16] H.R. Meena et al., Animal husbandry practices at high altitude ( $>6000$ feet) in Kumaon region of Uttarakhand, India, Livest. Res Rural Dev. 19 (2007) 11.

[17] Merwea, D.van der., Swana, G. E. and Botha, C. J.. Use of ethnoveterinary medicinal plants in cattle by Setswana-speaking people in the Madikwe area of the North West Province of South Africa, J. S. Afr. vet. Assoc. 72(4) (2001) 189-196.

[18] S. Mishra, S.S. Chaudhury, Ethnobotanical flora used by four major tribes of Koraput, Odisha, India, Genet. Resour. Crop Evol. 59 (2012) 793-804.

[19] S. Mishra et al., Wild edible tubers (Dioscorea spp.) and their contribution to the food security of tribes of Jaypore tract, Orissa, India, PGR. Newsletters. 156 (2008) 63-67.

[20] O. Phillips et al., Quantitative ethnobotany and Amazonian conservation, Conserv. Biol. 8 (1994) 225-248.

[21] P.C. Phondani, R.K. Maikhuri, C.P. Kala, Ethnoveterinary uses of medicinal plants among traditional herbal healers in alaknanda catchment of Uttarakhand, India, Afr. J. Trad. CAM. 7(3) (2010) $195-206$.

[22] C.H. Rahman, A. Ghosh, S. Mandal, Studies on the Ethno veterinary medicinal plants used by the tribes of Birbhum district, West Bengal, Indian J. Trad. Knowled. 33 (2009) 333-338.

[23] N. Rajakumar, M.B. Shivanna, Ethnomedicinal application of plants in the eastern region of Shimoga District, Karnataka, India, J. Ethnopharmacol. 126 (2009) 64-73.

[24] K.N. Reddy et al., Ethnoveterinary medicine for treating live stock in eastern Ghats of Andhra Pradesh, India, Indian J. Trad. Knowled. 5 (2006) 368-372.

[25] M.B. Rokaya, Z. Munzbergova, B. Timsina, Ethnobotanical study of medicinal plants from the Humla district of western Nepal, J. Ethnopharmacol. 130 (2010) 485-504.

[26] V. Satya, C.M. Solanki, Indigenous knowledge of veterinary medicines among tribes of West Nimar, Madhya Pradesh. Indian, J. Trad. Knowled. 33 (2009) 896-902.

[27] H.O. Saxena, M. Brahmam, 1994-1996. The Flora of Orissa. 4 vols. Orissa Forest Development Corporation Ltd. and Regional Research Laboratory, Bhubaneswar.

[28] J.R.S. Tabuti, S.S. Dhillion, K.A. Lye, Ethnoveterinary medicines for cattle (Bos indicus) in Bulamogi county, Uganda: plant species and mode of use, J. Ethnopharmacol. 88 (2003) 279286.

[29] A. Tariq et al., Ethnoveterinary Study of Medicinal Plants in a Tribal Society of Sulaiman Range, Scientific World J. (2014) 10. 
[30] R.T. Trotter, M.H. Logan, Informants consensus: a new approach for identifying potentially effective medicinal plants, in: N.L. Etkin (Ed.), Plants in Indigenous Medicine and Diet. Redgrave Publishing Company, Bedford Hill, NY, 1986, pp. 91-112.

[31] S.S. Yadav et al., Ethnoveterinary Medicinal Plants of Tosham Block of District Bhiwani (Haryana) India, J. App. Pharm. Sci. 4(6) (2014) 40-48.

[32] H. Yineger et al., Ethnoveterinary medicinal plants at Bale Mountains National Park, Ethiopia, J. Ethnopharmacol. 112 (2007) 55-70. 